\title{
Przestępczość jako zjawisko geograficzne? Przegląd badań nad zjawiskiem w świetle wybranych nauk Crime as a geographical phenomenon? Review of research from the standpoints of selected disciplines
}

\author{
Agnieszka Lisowska-Kierepka (ㄷ) \\ Uniwersytet Wrocławski \\ Wydział Nauk o Ziemi i Kształtowania Środowiska \\ ul. Kuźnicza 35, 50-138 Wrocław \\ agnieszka.lisowska@uwr.edu.pl
}

Zarys treści. Przestępczość stanowi tego rodzaju zjawisko, które bezpośrednio dotyka mieszkańców zasadniczo wszystkich obszarów na świecie. Jego zróżnicowanie, jeśli idzie o wielkość czy różnorodność popełnianych czynów, czyni je dodatkowo niezwykle niebezpiecznym. Wiele dziedzin naukowych zajmuje się jego analizą w różnych kontekstach próbując je wyjaśnić, czy ze strony lepszego poznania natury sprawcy - zaburzeń mających istotny wpływ na jego postępowanie, a zatem identyfikację różnych zjawisk chorobowych, które jednocześnie będą stanowić o konieczności izolacji takiej jednostki, czy też z punktu widzenia stworzenia odpowiedniego zestawu narzędzi będących pomocnymi w resocjalizacji jednostki, która dopuściła się czynu z prawem niezgodnego. Traktowanie zjawiska całkowicie odrębnie przez poszczególne nauki nie pozwoli na pełne jego zrozumienie, stąd też podkreśla się, że konieczna jest w tym kontekście współpraca wielu dyscyplin naukowych. Niniejsze opracowanie obejmuje przegląd badań dotyczących przestępczości jako zjawiska geograficznego ujmowanego pierwotnie w zakresie różnych dyscyplin naukowych. Współczesne rozważania nad zjawiskiem skupiają się w obrębie trzech podejść - kryminologicznego, socjologicznego i geograficznego i w taki sposób przeprowadzony został przegląd literatury. Celem pracy jest ukazanie zjawiska przestępczości w świetle różnych nauk, a także odpowiedź na pytanie czy i w jakim zakresie przestępczość jest zjawiskiem geograficznym.

Słowa kluczowe: przestępczość, przegląd badań, kryminologia, socjologia, geografia.

Keywords: crime, research review, criminology, sociology, geography.

\section{Wstęp}

Przestępczość jest tego rodzaju zjawiskiem, które oczywiście określa się jako istotne z punktu widzenia konieczności zapewnienia bezpieczeństwa mieszkańcom jednostek, w obrębie których występuje. Z drugiej strony jest także zjawiskiem interesującym pod różnymi względami - kim jest sprawca? dlaczego popełnił przestępstwo? czy zrobił to już w przeszłości? czy skłonności do popełniania przestępstw posiada się od urodzenia? czy są miejsca, w których częściej występują przestępstwa? Te i wiele innych pytań zadawali sobie, ale również współcześnie zadają, naukowcy, praktycy policyjni czy osoby zajmujące się resocjalizacją sprawców przestępstw. Jest to zatem zagadnienie wielowątkowe, które łączy w sobie kwestie dotyczące osoby sprawcy, ofiary, a także samych przyczyn występowania przestępczości w określonym miejscach i czasie, społeczeństwa czy grupach spo- 
łecznych. Czym jednak jest przestępczość? W niektórych aspektach pozostaje zjawiskiem nieco tajemniczym, nie do końca poznane są przecież motywacje podejmowania określonych decyzji przez sprawców przestępstw, nie można precyzyjnie wskazać także na czynniki, które warunkują postępowanie przestępcy. Jest to również zjawisko skomplikowane i to nie tylko z uwagi na problematykę rozważań nad naturą człowieka i jego skłonnościami, ale także z uwagi na wskazanie przyczyn występowania przestępczości w ogóle. Zakres badań nad przestępczością dawno już wykracza poza zainteresowania jednej dziedziny nauki, która stanowiłaby jedyną zajmującą się tymże zjawiskiem, jak to często jest przypisane niektórym zjawiskom. Występowanie przestępczości nie jest konsekwencją kilku prostych czynników, a efektem wielu różnych, które jednocześnie nie są do końca od siebie odrębne, stanowiąc pewną całość. Dlatego też błędnym byłoby analizowanie pojedynczych relacji przyczynowo-skutkowych, które tak naprawdę przy rozpatrywaniu zjawiska w sposób całościowy ulegają pewnemu zatarciu.

Przestępczość definiowana jest najogólniej jako zbiór zdarzeń, które można określić mianem przestępstw. Dodając do tej definicji elementy związane z określonym obszarem lub społecznością, to tego rodzaju zjawisko określić można będzie mianem tzw. przestępczości rzeczywistej. Jednak jeśli pod uwagę wzięte zostaną te zdarzenia, które zostały odnotowane, ale również uznane i zarejestrowane jako przestępstwa przez odpowiednie organy ścigania to wówczas mowa będzie o przestępczości ujawnionej. Nie wszystkie czyny są jednak ujawniane czy też rejestrowane, co wynikać może z różnych kwestii, stąd też istnieje również taka przestępczość, o której niewiele wiadomo - tzw. przestępczość nieujawiona. Oczywiście może być ona analizowana na podstawie relacji świadków przestępstw lub zeznań samych sprawców, niemniej jednak badania te nigdy nie będą w pełni oddawały wielkości tego zjawiska (Błachut i inni, 2007). Na fakt istnienia przestępczości nieujawnionej wpływa wiele różnych czynników. B. Hołyst (2009) jako najistotniejszy wskazuje zaniechanie zgłoszenia przestępstwa, co jest lub może wynikać z różnych kwestii. Do pozostałych przyczyn, które decydują o istnieniu tej tzw. ciemnej liczby przestępstw zalicza się m.in.: sposób organizacji oraz wielkość poszczególnych organów ścigania, politykę ścigania, ale również jakość pracy funkcjonariuszy związanych z organami ścigania oraz sprawiedliwości (zwłaszcza sądownictwem), sposób w jaki rejestrowane są zgłoszenia, zaufanie społeczne do organów i instytucji ścigania i wymiaru sprawiedliwości i związaną z tym skłonność obywateli do zgłaszania faktu popełnienia przestępstwa. Autor podkreśla także, że poza czynnikami tkwiącymi w samych ofiarach przestępstw lub organizacji odpowiednich służb, współcześnie można wymienić kilka obszarów tzw. ciemnej liczby przestępstw - przyczyn o innym charakterze, które powodują, że informacja statystyczna pozostaje pozbawiona pewnej liczby zdarzeń. Jako pierwszą wskazuje najbardziej oczywistą, a zatem przestępstwa, które nie zostały zgłoszone na policję, druga obejmuje tę grupę zdarzeń, których sprawcy nie zostali wykryci, kolejna dotyczy przestępców ujawnionych, ale ze względu na negatywne przesłanki procesowe nie wniesiono aktu oskarżenia i ostatnia związana jest ze skazaniem oskarżonych w szerszym zakresie niż było to zarejestrowane przez jednostki policyjne (Hołyst, 2009).

Na fakt popełnienia przestępstwa składa się kilka zasadniczych czynników, mianowicie należy wskazać tu sprawcę przestępstwa, ofiarę/cel, miejsce i czas. Wszystkie stanowią o wystąpieniu zdarzenia w różnych aspektach, a każdy z nich może być rozpatrywany przez różne nauki. Stąd też zjawisko to określane jest często mianem multi-, ale również interdyscyplinarnego. Wynika to przede wszystkim z jego złożoności. Każdy z elementów 
składających się na przestępstwo może być czy też był rozpatrywany odrębnie w ramach różnych dyscyplin naukowych zgodnie z podejmowaną przez nie problematyką. Jednak przy całościowej ocenie zjawiska i jego analizie koniecznie jest wspieranie się dorobkiem wielu różnych nauk. Ma to proste uzasadnienie - wiele z nich wypracowało w swojej bogatej historii istotny zespół rozwiązań, które przyczyniły się i wspomagają wyjaśnienie tejże problematyki. Niemniej jednak początkowo to sprawca i ofiara przestępstwa stanowili najważniejsze zagadnienia rozpatrywane w ramach badań nad zjawiskiem. Miejsce, czy też przestrzeń, w zakresie tego rodzaju rozważań, pojawiły się późno - dopiero w XIX w. Początkowo przestrzenne analizy zjawiska obecne były przede wszystkim pod postacią map, na których oznaczano dokonane przestępstwa, a następnie interpretowano powstałe w ten sposób obrazy. Wśród pierwszych opracowań wymienia się przede wszystkim prace kartograficzne wykonane dla Francji i Wielkiej Brytanii przez A.M. Guerry'ego i A. Queteleta (Friendly, 2007).Wskazuje się, że analizy przestrzenne na stałe pojawiły się w opracowaniach przedstawicieli różnych nauk dopiero w II połowie XX w. (Mordwa, 2013). To wówczas zauważono, że przestrzeń, poza samym sprawcą przestępstwa i ofiarą odgrywa istotną rolę - zwłaszcza w kontekście cech ją charakteryzujących i działań jakie należałoby podjąć w celu zapewnienia większego bezpieczeństwa, a tym samym ograniczenia zjawiska. Tematyka związana z kształtowaniem przestrzeni, we wspomnianym kontekście, była przedmiotem rozważań różnych dyscyplin naukowych, jednak najszerzej omówiona została ona w ramach kryminologii, a właściwie nurtu który się tu wykształcił - kryminologii środowiskowej. Kierunek ten bardzo mocno podkreśla istotność miejsca wobec okazji do popełnienia przestępstwa. Przy wykorzystaniu opracowań kartograficznych wskazuje na związki między popełnieniem przestępstwa a zagadnieniami użytkowania terenu, projektów rozwiązań przestrzennych, strukturą urbanistyczną, a także codzienną aktywnością mieszkańców - wśród nich zarówno ofiar oraz sprawców. Przestrzeń, czy też jej kształtowanie i cechy mają wpływ także na kreowanie więzi międzyludzkich oraz tworzenie i zachowanie wspólnot - te zagadnienia poruszane są z kolei w ramach socjologii, a także socjologii miasta. Tu należy podkreślić dokonania chicagowskiej szkoły ekologicznej, w ramach której analizowano związki między przestępczością, a różnymi uwarunkowaniami - w tym także przestrzennymi. W związku z tym, że owa przestrzeń podlega zasadniczo kształtowaniu i gospodarowaniu, wskazuje się, że rozważania w tym zakresie stanowią z kolei właściwość nauk geograficznych, a zwłaszcza geografii społecznej. Z kolei już projektowanie odpowiednich rozwiązań przestrzennych w powiązaniu z zapobieganiem przestępczości stanowi przedmiot zainteresowań planowania przestrzennego, urbanistyki czy architektury (Czarnecki, 2011). Czy przestępczość jest zjawiskiem geograficznym? Z pewnością geograficzne badania nad zjawiskiem przestępczości stanowią współcześnie istotny dorobek naukowy, który wspomaga analizy nad przestępczością. Odpowiedź na tak postawione pytanie umożliwi przegląd badań nad zjawiskiem w ujęciu różnych nauk.

\section{Przegląd badań nad przestępczością w ujęciu różnych nauk}

Pierwsze naukowe analizy na temat zjawiska pojawiły się stosunkowo późno, co najprawdopodobniej wynikało przede wszystkim z braku odpowiednich narzędzi i rozważań nad rzekomą winą sprawcy - karano szybko i zwykle zgodnie ze starożytną zasadą „oko za oko”. Dopiero w XIX w. mimo całej surowości w wymierzaniu kar zaczęto zastanawiać się nad 
postępowaniem przestępcy, pobudkami czy motywacjami, które doprowadziły do podjęcia przez niego określonej decyzji. Pierwsze badania skupiały się przede wszystkim na osobie sprawcy, to właśnie w nim upatrując przyczyn takiego, a nie innego zachowania. Pod uwagę brano przede wszystkim kwestie jego fizjonomii, mianowicie powszechne było stwierdzenie, że przestępcą człowiek się po prostu rodzi - wynika to z cech anatomicznych, które warunkują skłonności do określonych zachowań. Podejście to bardzo szybko zostało odrzucone i współcześnie wspomina się je przede wszystkim w kontekście historycznym, niemniej jednak badania biologiczne nie straciły na znaczeniu, a ciężar badań przeniosły na różnego rodzaju przemiany czy procesy fizjologiczne, jak również środki medyczne czy inne, które mogą mieć znaczenie dla będącego pod ich wpływem człowieka na podejmowane przez niego decyzje, a co za tym idzie także jego postępowanie. W taki kontekst wpisują się również badania w sferze psychologii czy socjologii, które poszerzają rozważania w tym zakresie. W przypadku obu nauk istotnym zagadnieniem analizowanym w odniesieniu do przestępczości staje się osobowość człowieka - przy czym psychologia zajmuje się przede wszystkim analizą przemian tejże osobowości i motywami sprawcy, natomiast socjologia w nieco szerszym kontekście porusza wynikający z niej stosunek do otaczającego środowiska, społeczeństwa etc. W takim ujęciu motywacje sprawcy rozpatrywane są przede wszystkim z punktu widzenia tego co, ujmować można nieco patetycznie, odbywa się w jego wnętrzu. Do kwestii opłacalności tego rodzaju postępowania, analizy nad zjawiskiem sprowadza ekonomia, wskazując, że działanie człowieka czy to pozytywne, a w tym kontekście zgodne z prawem, czy negatywne-odpowiednio odwrotnie, wynika z prostego rachunku zysków i strat.

Zapoczątkowanie badań nad przestępczością jako zjawiskiem wywołało rozważania w obrębie różnych dziedzin naukowych, o czym już wspomniano, w ramach których każda z nauk w odmienny - właściwy dla siebie sposób próbowała wyjaśniać różne kwestie, które miały wpływ na pojawienie się przestępczości w ogóle. Poza wymienionymi powyżej wskazać należy także m.in. historię, która zajmowała się przede wszystkim zagadnieniem w kontekście zmian rozwoju społeczeństw, sposobów karania i ich wpływu na kształtowanie wielkości zjawiska; religioznawstwo - kwestie dopuszczalności określonego postępowania z wyznawanym systemem wartości, kultem etc., czy nauki polityczne, filozofię, pedagogikę -analiza postępowania określonej jednostki biorąc pod uwagę m.in. jej przekonania, postrzeganie świata w globalnym ujęciu, moralność przestępcy w odniesieniu do jego działania a także rozważania nad wpływem systemów sprawiedliwości na funkcjonowanie poszczególnych jednostek, społeczeństw oraz kwestie wychowania sprawców określonych przestępstw i podejmowanie w stosunku do nich odpowiednich działań naprawczych (Mordwa, 2015).

Nie ulega wątpliwości, że ze względu na ważkość omawianej problematyki, zaczęto ją analizować w rozmaitych kontekstach. Jednakże były to badania obejmujące pewne odrębne, czasem nawet wąskie zagadnienia, które nie do końca pozwalały na pełne zrozumienie zjawiska. Odpowiedzią na takie rozdrobnienie badań była początkowo kryminologia. Bardzo szybko jednak, obok analiz kryminologicznych, wykształciło się podejście socjologiczne, a w jego ramach dość rozbudowane teorie objaśniające występowanie zjawiska. Obie nauki czy też oba podejścia skupiały się przede wszystkim na osobie sprawcy, w różnych aspektach. Wraz z rozwojem rozważań nad przestępczością dostrzeżono znaczenie także innych czynników, które mogą mieć wpływ na występowanie przestępczości w określonych warunkach, przy czym dopiero ich rozpatrywanie całościowo daje pełny 
obraz zjawiska - tak rozwinęło się podejście przestrzenne, geograficzne. Współcześnie wydaje się, że wszelkie badania, rozważania czy koncepcje, nawet jeśli tworzone przez przedstawicieli różnych nauk, zamykają się w ramach trzech wymienionych już podejść - kryminologicznego, socjologicznego i geograficznego. Powyższe rozróżnienie opiera się przede wszystkim na odmiennej metodologii, stąd też w niniejszym przeglądzie badań, przy charakterystyce poszczególnych podejść nie zaakcentowano przynależności autorów prac do określonych dyscyplin.

\section{Podejście kryminologiczne}

Przestępczość od początku rozważań najsilniej związana była z naukami prawnymi, kryminologicznymi czy kryminalistycznymi. Stąd też w najpełniejszym stopniu to właśnie w ramach kryminologii rozważano przyczyny wystąpienia zjawiska, jak również wszystkie jego elementy. Badania kryminologiczne należą do najstarszych, a jednocześnie dość interdyscyplinarnych ze względu na fakt zgromadzenia w ramach dorobku tej nauki wielu teorii, bardzo często obejmujących swoim zakresem przedmiot badań innych dyscyplin naukowych. W ramach kryminologicznych rozważań nad zjawiskiem można w dużym uproszczeniu wskazać trzy podejścia: biologiczne, socjologiczne i sytuacyjne.

Podejście biologiczne od początku opierało się przede wszystkim na cechach człowieka wrodzonych lub też nabytych i objęło swoim zakresem rozważania w zakresie czynników sensu stricte biologicznych, ale również biopsychologicznych czy psychologicznych, a zatem plasujących się przede wszystkim w zakresie badań nauk biologiczno-medycznych. Jako główny czynnik sprzyjający zjawisku przestępczości wskazywane jest dziedziczenie cech przestępczych lub skłonności, bądź też nabycie takowych w wyniku różnorodnych zdarzeń, wśród których można wskazać: schorzenia i/lub uszkodzenia mózgu przed urodzeniem lub we wczesnym dzieciństwie, wady genetyczne lub wrodzone zaburzenia osobowości. Wśród najważniejszych koncepcji należy z całą pewnością wskazać następujące: „przestępcy z urodzenia” C. Lombroso (Lombroso, 1891), która dała przyczynek do badań nad kwestiami dziedziczenia określonych skłonności do zachowań niewłaściwych, a w tym zakresie określonych badań (genealogicznych, bliźniąt czy adopcyjnych) (Błachut i inni, 2007); Hipokratesa dotyczącą wyróżnienia czterech typów psychosomatycznych - sangwinika, choleryka, melancholika oraz flegmatyka oraz cech uzasadniających postępowanie człowieka; Kretschmera wskazującą cztery typy somatyczne łączone z różnymi skłonnościami do chorób psychicznych - typ asteniczny, atletyczny, pykniczny i dysplastyczny, teoria H. Eysnecka wskazującą na dwa przeciwstawne, ale uwarunkowane biologicznie typy układu nerwowego zróżnicowane co do szybkości procesów pobudzenia i wyhamowania emocjonalnego - ekstrawertycy i introwertycy - autor łączył tu uwarunkowania biologiczne $z$ indywidualną podatnością na proces socjalizacji, która jego zdaniem miała bardzo istotne znaczenie (Eysenck, 2013). Podobne badania podejmowane były również w Polsce przez W. Sanockiego, K. Pospiszyl i J. Stanik (Błachut i inni, 2007). Mimo znacznej krytyki koncepcji wykształconych w ramach podejścia biologicznego wskazuje się, że mają one istotne znaczenie w dorobku badań nad przestępczością w nieco innym zakresie. Mianowicie koncepcje te przyczyniły się do zindywidualizowanego podejścia do sprawców różnorodnych przestępstw, jak również wymierzania odpowiednich kar, czy środków karnych lub zabezpieczających, co ma istotne znaczenie zwłaszcza w kontekście osób chorych psychicznie, a także tych, które w jakikolwiek sposób zagrażają otoczeniu. 
Kierunek socjologiczny w zakresie badań kryminologicznych nad przestępczością rzadko występuje samodzielnie, jest raczej związany z ogólnym funkcjonowaniem społeczeństwa, a raczej jego zróżnicowaniem i badaniami o charakterze przestrzennym. Jako główne uwarunkowania sprzyjające pojawieniu się zjawiska przestępczości wskazuje się cechy społeczne - ubóstwo, bezrobocie, migracje, konflikty między mieszkańcami miast, alkoholizm czy narkomanię. Do takiego podejścia w kryminologii, które skupia się nie tylko na osobie przestępcy, ale na przestępczości jako pewnym zjawisku społecznym nawiązują jedne ze starszych rozważań m.in. wspomnianego A. Queteleta (Quetelet, 1842), a wskazuje się w tym zakresie także na istotne badania tzw. szkoły socjologicznej prawa karnego, która reprezentowana było przez Franza von Liszta (von Liszt, 1905). Należy podkreślić także, że w literaturze wskazuje się, że kierunek socjologiczny występujący w ramach kryminologii pozytywistycznej reprezentowany jest przez teorie wykształcone w ramach de facto socjologii (teorie ekologiczne, strukturalne, zróżnicowania kulturalnego, uczenia się etc.), a początkowo zdefiniowane w zakresie badań kryminologicznych (Błachut i inni, 2007). Socjologia wykształciła w swoim zakresie subdyscyplinę zajmującą się przestępczością, w nieco jednak innym kontekście i tam należałoby umiejscowić powstałe teorie. Stąd też niektóre z nich zostaną szerzej omówione w ramach podejścia socjologicznego. W tym miejscu należy jedynie zaznaczyć, że kierunek socjologiczny bardzo często pojawia się w ramach kryminologii pozytywistycznej uwzględniając dorobek socjologów.

W przypadku kierunku sytuacyjnego, który uwzględnia czynnik przestrzenny jako istotny w zakresie analiz nad przestępczością istotne znaczenie mają przede wszystkim okazje/sytuacje, które ze względu na specyficzne uwarunkowania, m.in. przestrzenne (np. zagospodarowanie przestrzeni, obiekty) sprzyjają działaniu potencjalnych sprawców przestępstw. Uznano także, że podejście przestrzenne jest nieco szersze, poza czynnikami przestrzennymi obejmuje także szereg innych uwarunkowań, które dopiero w całości stanowią możliwe uzasadnienie pojawienia się przestępczości, a właściwie jej nasilenia (Hanausek, 1998). Wieloaspektowość analiz nad zjawiskiem spowodowała wykształcenie subdyscypliny - kryminologii środowiskowej, która zmieniła postrzeganie przestępczości jako odrębnego zjawiska, a nie formę zwrócenia uwagi na różne problemy powstałe w społeczeństwie lub też manifestację niewłaściwych warunków społeczno-gospodarczych. W jej ramach zmieniono nieco prowadzenie dotychczasowych analiz, które skupiały się przede wszystkim na osobie sprawcy, nie rozpatrując innych czynników - podkreślono znaczenie aspektów przestrzennych oraz innej perspektywy - środowiskowej czy geograficznej, w ten sposób nieco odchodząc od podejścia stricte socjologicznego (Brantingham i Brantingham, 1991). Istotność pojawienia się kryminologii środowiskowej uzasadniana jest przede wszystkim zakresem analiz, które obejmują miejsce przestępstwa w sposób całościowy, tj. pod uwagę brane są kwestie nie tylko związane z zagospodarowaniem lub zabudową określonego obszaru, ale także sposobem ich użytkowania czy też wpływem funkcjonujących tam grup społecznych charakteryzujących się określonymi cechami (Doran i Lees, 2005). W ramach tego nurtu badań wskazano, że zachowanie przestępcze stanowi, podobnie jak inne, swego rodzaju interakcję jaka następuje pomiędzy osobą i sytuacją. Nie małą rolę odgrywa tu również środowisko, które wpływa na inicjację oraz przebieg określonego postępowania. Wskazuje się, że fakt popełnienia przestępstwa jest następstwem nie tylko cech samego sprawcy, ale również kryminogennych cech środowiska. Ponadto skoro otoczenie ma istotny wpływ na popełnienie przestępstwa to rozmieszczenie przestępstw może zależeć od rozmieszczenia tych funkcji zagospodarowania, 
których oddziaływanie może wpływać na występowanie i jednocześnie nasilenie konkretnych rodzajów przestępstw. Natomiast przestępstwa mają tendencję do koncentracji w miejscach, które stwarzają okazję i jednocześnie z różnych względów łatwiej je tam popełnić. To w efekcie prowadzi do powstania zarówno w przestrzeni, jak i w czasie swego rodzaju struktur rozmieszczenia zjawiska, których znajomość stanowi bardzo ważny czynnik w zakresie działań prewencyjnych (Wortley i Mazerolle, 2008). Wśród teorii, powstałych w ramach tego nurtu kryminologii, wskazuje się na trzy podstawowe: racjonalnego wyboru, działań rutynowych oraz schematów zachowań przestępczych (Eck i Weisburd, 1995). Wydaje się jednak, że powyższe teorie stanowią przede wszystkim przyczynek do badań przestrzennych w ramach kryminologii, dalsze rozważania kryminologiczno-przestrzenne, z uwagi na charakter metod jakie zostały zastosowane oraz przewagę czynników przestrzennych w tych rozważaniach należałoby zaliczyć do rozważań na pograniczu geografii i kryminologii i tak też je omówić.

Poza ujęciem kryminologii środowiskowej, która w zakresie badań przestępczości podkreśla istotność środowiska otaczającego jednostkę w podejmowaniu przez nią decyzji przestępnych, należy wskazać także na inne kierunki jakie ukształtowały się w ramach całej nauki, a związane są z analizą przestępczości w różnych aspektach. Wśród takich można wymienić: (1) kryminologię feministyczną, która swoim zakresem obejmuje rolę kobiet w zjawisku przestępczości, zwłaszcza w kontekście ich wiktymizacji; (2) kryminologię konfliktową, która zakłada, że przestępczość jest zjawiskiem nieuniknionym w społeczeństwach kapitalistycznych - w każdym społeczeństwie można wskazać na takie grupy, które z jakichś powodów są marginalizowane, co może skłaniać ich członków do wkroczenia na drogę przestępstwa w celu wyrównania istniejących nierówności; (3) kryminologię krytyczną obejmującą swoim zakresem teoretyczne rozważania nad genezą przestępczości oraz interpretacji pojęcia sprawiedliwości w odniesieniu do nierówności klasowych; (4) kryminologię kulturową, której celem jest wyjaśnienie występowania zjawiska przestępczości w kontekście kulturowym; (5) kryminologię narracyjną skupiającą się przede wszystkim na analizie roli jaką pełnią opowiadania czy dzielenie się różnymi historiami w popełnieniu lub wywieraniu wpływu na podjęcie decyzji o popełnieniu przestępstwa czy innego niepożądanego działania; (6) kryminologię publiczną, która ukierunkowuje badania przestępczości uwzględniając $w$ tym zakresie konsultacje ze społecznościami dotkniętymi tym zjawiskiem w większym nasileniu oraz (7) tzw. zieloną kryminologię, której przedmiotem badań są przestępstwa skierowane przeciwko środowisku, zwierzętom i ludziom przez duże instytucje takie jak rządy państw, korporacje etc. (Drzazga i Grzyb, 2018).

Podkreślić należy zatem, że przestępczość analizowana jest najszerzej przez kryminologię, która jako najstarsza i jednocześnie dominująca w tym zakresie nauka analizuje zjawisko w różnych kontekstach, niemniej jednak zazwyczaj skupia się na samym fakcie popełnienia przestępstwa odnosząc się do różnych czynników. Zasadniczo jedynie kryminologia środowiskowa uwzględnia w szerszym zakresie miejsce popełnienia przestępstwa i czynniki z tym związane, stąd też została omówiona nieco szerzej w ramach tego podejścia. 


\section{Podejście socjologiczne}

Przestępczość traktowana jako czyn człowieka stała się nieuchronnie przedmiotem rozważań nauk, które zajmują się ściśle człowiekiem, jego motywacjami, a także funkcjonowaniem w większej zbiorowości. Nauką, która wypracowała dość istotny zestaw różnych koncepcji w tym zakresie jest socjologia. Jednakże przestępczość traktowana jest tu przede wszystkim jako fakt, pewne wydarzenie społeczne, które ze względu na swoisty charakter podlega badaniom socjologicznym. Ponadto należy je także w tym kontekście uznać za zachowanie dewiacyjne, a zatem takie, które jest niezgodne z wszelkimi przyjętymi systemami wartości, obyczajami, wartościami moralnymi lub też po prostu obowiązującymi zasadami prawa (Sztompka, 2002). Za działanie przeciwko określonym zasadom przewidziana jest zwykle sankcja. Przy tak rozumianym pojęciu przestępstwa, nieuniknione staje się traktowanie go jako pewnego konstruktu społecznego, co jest efektem wykształconego i utrwalonego przez określone społeczeństwo pewnego katalogu norm, zwyczajów czy też moralności wyznaczającej wzorce zachowań. Zatem o tym czy popełniono przestępstwo decyduje przede wszystkim to czy określone postępowanie, według ustalonego katalogu zostanie w taki sposób skategoryzowane, a przestępcą staje się ten, kto nie przestrzega ustalonego systemu zasad lub postępuje niezgodnie z nim (Błachut, 2007).

$\mathrm{Na}$ podstawie prowadzonych badań wypracowano różne koncepcje, które miały na celu przede wszystkim wyjaśnić bądź też uzasadnić problematykę przestępczości i jej występowania w społeczeństwie. Zostały one pogrupowane w trzy kategorie, które w różny sposób starają się wyjaśniać zjawisko przestępczości (Lisowska-Kierepka, 2019):

1. koncepcje uwzględniające jako najważniejszy czynnik wpływ społeczeństwa, w ramach którego wskazać należy na naciski czy presję ze strony tego społeczeństwa, co wynika z określonych wcześniej zakorzenionych oczekiwań. Poszczególne jednostki uznaje się za bierne, bez prawa do decydowania o swoim postępowaniu, o nim decyduje grupa, w której funkcjonuje jednostka. Jako przykład można tu wskazać koncepcję R. Mertona - wyraźna rola otoczenia jednostki, a także wywieranej na nią presji, która ma istotne znaczenie w kontekście określania celów i środków do ich realizacji (Merton, 1982); koncepcję A. Cohena „przestępczej podkultury” - w społeczeństwie istnieje warstwa, która decyduje o tym co jest miarą sukcesu, a co nie i wskazuje w jaki sposób należy się zachowywać. Ta klasa społeczna złożona jest z osób pełniących różne funkcje w instytucjach kontroli społecznej, a osiągnięcie wyższej pozycji społecznej możliwe jest dzięki osiągnięciu określonych cech lub spełnienie wyznaczonych kryteriów (Cohen, 1955)

2. koncepcje, w których główne założenie opiera się na przekonaniu, że przestępczość jest zjawiskiem nieuniknionym w każdym społeczeństwie, a kwestią nad jaką należy się skupić jest utrzymanie poziomu zjawiska na odpowiednim poziomie. Wśród twórców takich teorii należy wymienić: E. Durkheima - przestępczość nie jest zaburzeniem społecznym, jest zjawiskiem, które zawsze występuje w każdym ze społeczeństw, co wynika z odpowiedniego określenia jakie zjawiska są niepożądane. Poza tym jego zdaniem każda dewiacja (tak określa przestępczość) odgrywa rolę w funkcjonowaniu społeczeństwa - służy wyznaczaniu odpowiednich idei, a także rozgraniczeniu dobra i zła (Giddens i Sutton, 2012); W. Millera - koncepcja wskazująca, że zachowania kryminalne należą do normalnych, charakterystycznych dla niższych grup społecznych (Miller, 1958); T. Hirschiego i M. Gottfredsona - koncepcja 
ogólnej teorii przestępczości, w której istotną rolę pełni słaba samokontrola wynikająca z niewłaściwego, wadliwego wychowania skutkująca większymi skłonnościami do zachowań przestępczych przy założeniu jednego, uniwersalnego systemu norm i wartości (Gottfredson i Hirschi, 1990), a także inne koncepcje naznaczenia społecznego

3. koncepcje, które przyjmują za istotne oddziaływanie różnych wpływów społecznych, ale przy tym uwzględniają również możliwości jednostki w zakresie nabywania nowych umiejętności, które wykorzystane zostaną zgodnie z wyznawanym systemem wartości, jak również stosunkiem jednostki do niego, np. koncepcja A. Cloward i L.E. Ohlin (1960) - koncepcja zróżnicowanych okazji wskazująca, że wybór postępowania niezgodnego z prawem wynika zarówno z wpływu środowiska, ale również innych czynników takich jak dostępność środków, narzędzi czy też systemu wartości i wzorców w jakich jednostka została ukształtowana; E. Sutherland (1947) - koncepcja zróżnicowanych powiązań - początek rozważań nad prześledzeniem procesu wyboru postępowania niezgodnego z prawem, niemniej jednak jeszcze nie do końca zinterpretowanego, rozwinięta przez A. Bandurę (1979) - istotnym elementem staje się spotkanie jednostki z postępowaniem przestępnym, a następnie wszystko, co w tym zakresie jednostka zapamiętuje. Wyuczone umiejętności podlegają w tym zakresie różnorodnym wpływom, które mogą być wzmacniane i utrwalane lub odwrotnie, co zależne jest od rodzaju oddziaływań zewnętrznych. Co istotne jednak, że jednostka potrafi kontrolować swoje postępowanie i decydować w jaki sposób ma ono przebiegać.

Z pewnością można doszukać się również innych teorii, które rozwijają lub uszczegóławiają powyżej wymienione, ale już na tej podstawie można wywnioskować, że specyfiką podejścia socjologicznego jest przede wszystkim skupienie na społeczeństwie, które wywiera określony wpływ na jednostkę, a w dalszej kolejności na jednostce, która funkcjonuje w większej grupie jaką jest społeczeństwo. Tam kształtuje swoje postawy, system wartości etc.

W kontekście badań socjologicznych należy zwrócić uwagę na bardzo ważny kierunek ekologiczny, który został następnie wprowadzony do analiz kryminologicznych i wykorzystany w syntetycznych opracowaniach, a który jednocześnie jest zupełnie odmienny od przytoczonych powyżej zagadnień. Swoim zakresem obejmuje interakcje miedzy zachowaniami przestępczymi a szeroko rozumianym środowiskiem zarówno fizycznym, jak również społecznym. Niemniej jednak zwykle wskazuje się na większą doniosłość tego rodzaju rozważań w zakresie powiązań zdarzeń przestępczych z czynnikami społecznymi czy przestrzenią miasta. Badania w tym zakresie prowadzili przede wszystkim twórcy tzw. szkoły chicagowskiej, do których zaliczyć należy m.in.: R. Park’a - teoria porównująca społeczność do świata roślin i zwierząt - istotne znaczenie grup silniejszych, bardziej przedsiębiorczych, które pozyskują dla siebie przestrzenie lepsze, bardziej atrakcyjne (Park, 1979), E. Burgess'a - koncepcję koncentrycznego rozwoju miasta i związanych z tym przekształceń także w strukturze społecznej (dezorganizacja społeczna) (Błachut i inni, 2007), C. Shaw'a i H. McKay’a - badania nad zróżnicowaniem przestrzeni miejskiej pod względem cech panujących w każdej z pięciu wyróżnionych stref oddziałujących na zachowania ich mieszkańców (Shaw i McKay, 1942). 


\section{Podejście geograficzne czy przestrzenne?}

Zjawisko przestępczości traktowane jest nie tylko jako to, które ma związek z przestrzenią, ale również to, na którego powstanie składa się wiele różnych czynników. W literaturze wskazuje się, że przestępczość ma swój wymiar przestrzenny, co przejawia się przede wszystkim poprzez występowanie obszarów o większym i mniejszym nasileniu występowania zjawiska (Mordwa, 2013). Analizy przestępczości w ujęciu geograficznym stały się przedmiotem stosunkowo nowej subdyscypliny - geografii przestępczości. Początkowo nawiązywała ona silnie do wspominanego już ekologicznego kierunku badań społecznych, jednak wraz z postępem technologicznym (szczególnie rozwój metod i technik w ramach oprogramowania GIS - Geographic Information System) przedmiot analiz znacznie się rozszerzył obejmując swoim zakresem coraz to nowsze zagadnienia.

Geografia przestępczości w literaturze światowej definiowana jest jako subdyscyplina, której rozważania koncentrują się przede wszystkim w obrębie wyjaśniania interakcji jakie zachodzą miedzy przestępczością, przestrzenią oraz społeczeństwem, co umożliwiają analizy obejmujące swoim zakresem przestępstwa, przestępców i konsekwencje jakie wiążą się z przestępczością (Gregory i inni, 2009). Współczesna geografia ma na celu zatem nie tylko przedstawianie miejsc, w których występuje przestępczość, ale również interpretację oraz wyjaśnienie związków między przestępczością a przestrzenią. Ponadto istotnym zagadnieniem staje się również analiza właściwości miejsc cechujących się większym nasileniem zjawiska (Herbert, 1989). W zakresie badań geografii przestępczości zdefiniowano dwa kierunki badawcze - tzw. obiektywny oraz subiektywny. Obiektywny opiera się na danych statystycznych udostępnianych przez jednostki policyjne i obejmuje swoim zakresem rozważania nad zróżnicowaniem i dynamiką zjawiska w różnych odniesieniach przestrzennych i wskazaniem miejsc, które są w sposób szczególny zagrożone wystąpieniem przestępczości. Natomiast drugi kierunek - subiektywny, obejmuje badania związane z percepcją przestępczości oraz obawą czy strachem przed nią, a informacje na ten temat pozyskiwane są w wyniku badań ankietowych wśród mieszkańców (Maik, 1995; Czyż, 1996; Bogacka, 2017). Dane jakie udostępniane są do analiz, a przede wszystkim ich postać, silnie determinują analizy nad zjawiskiem, niemniej jednak pojawiające się opracowania plasują się zasadniczo w obrębie wskazanych kierunków.

Jako jedna z młodszych subdyscyplin zajmujących się przestępczością, geografia przestępczości nie wykształciła koncepcji teoretycznych mających na celu wyjaśnienie zróżnicowania przestrzennego występowania zjawiska. Można wskazać trzy podstawowe teorie, które właściwie narodziły się w ramach rozważań kryminologicznych, ale mają bardzo istotne elementy związane z przestrzenią lub geografią jako taką, przez co można byłoby je w dużym uproszczeniu traktować jako „kryminologiczno-geograficzne”. Do nich zalicza się następujące: teorię wzorca zachowań przestępczych, teorię racjonalnego wyboru oraz teorię działań rutynowych. Teoria racjonalnego wyboru powstała w ramach badań ekonomicznych i zakładała, że ludzkie zachowania w każdej sferze opierają się prostym rachunku zysków i strat. Ludzie oceniają warunki i wszelkie czynniki, które panują w miejscu i czasie ich działania w taki sposób, aby zmaksymalizować spodziewane zyski, przy stosunkowo niewielkich kosztach własnych (Mordwa, 2013). Mimo, że teoria powstała na gruncie badań ekonomicznych bardzo szybko przełożono ją i wykorzystano w analizach przestrzennych działań sprawców przestępstw - istotne znaczenie przy ocenie tzw. opłacalności postępowania będą miały również uwarunkowania przestrzenne np. zacienione 
miejsca, pozbawione nadmiernego ruchu pieszych, a zatem pozostające poza jakąkolwiek kontrolą będą sprzyjać potencjalnym przestępcom bardziej niż przykładowo galerie handlowe, gdzie znajduje się wiele różnych form kontroli.

Teoria działań rutynowych, była z kolei tą, która powstała na podstawie teorii racjonalnego wyboru. Głównym jej zadaniem było objaśnianie sposobu postępowania sprawcy przestępstwa, dla którego ważne były trzy elementy - przestępca, a zatem odpowiednio zmotywowana do działania jednostka; cel, który musi stanowić istotną atrakcję dla sprawcy -przez co decyduje się on na działanie niezgodne z prawem i ostatni z elementów - brak kontroli, co umożliwia sprawcy działanie. Jednak dopiero zbieg wszystkich tych elementów w jednym czasie i miejscu decyduje o możliwości działania odpowiednio zmotywowanego sprawcy. Podstawowym założeniem tej teorii było przekonanie, że sprawcy zazwyczaj dokonują czynów zabronionych w miejscach dobrze im znanym, a zatem tym w których funkcjonują. Warto zwrócić także uwagę na kwestię kontroli nieformalnej, która dopóki istnieje, stwarza swego rodzaju ograniczenia dla działań potencjalnego sprawcy (Felson i Gottfredson, 1984; Felson, 2009).

Ostatnia z wymienionych teorii - wzorców zachowań przestępczych lub też inaczej schematów zachowań przestępczych stworzona przez P. i P. Brantingham zakładała, w uproszczeniu, że prawdopodobieństwo popełnienia czynu przez określonego sprawcę zmniejsza się wraz ze zwiększeniem odległości od miejsca zamieszkania (Brantingham i Brantingham, 1991). Uwzględnia ona obie wskazane powyżej teorie dodając własne założenia. Zgodnie z nią można wskazać na występowanie określonych elementów, które mają istotne znaczenie przy podejmowaniu decyzji przez potencjalnego sprawcę przestępstwa: tzw. przestrzeń działania (action space), która stanowi miejsce zwykłego funkcjonowania sprawcy, w jej obrębie z kolei można wyróżnić tzw. miejsca węzłowe (nodes), są to miejsca rutynowej działalności takie jak mieszkanie, centra lub galerie handlowe, miejsca pracy, szkoły, obszary rekreacyjne oraz miejsca rozrywkowe. Całość tej przestrzeni dopełniają ścieżki (paths). Potencjalny przestępca porusza się w tej przestrzeni działania stopniowo przekształcając ją w tzw. przestrzeń świadomości (awareness space), powstaje ona jak sama nazwa wskazuje w świadomości jednostki, to na niej zostają zlokalizowane i skonkretyzowane cele.

Na podstawie tak określonych schematów działań sprawcy powstawały także koncepcje, których celem stało się zapobieganie lub eliminacja zjawiska przestępczości w określonych przestrzeniach. Do jednej z nich, ale jednocześnie zdaje się najbardziej popularnej, zaliczyć należy koncepcję defensible space O. Newmana. Dotyczyła ona odpowiednio zaprojektowanej i zagospodarowanej przestrzeni, w taki sposób, żeby odstraszyć potencjalnego sprawcę. Głównym czynnikiem, który miałby w jakiś sposób ograniczać wielkość zjawiska, byliby sami mieszkańcy sprawujący kontrolę w obszarze, w którym przebywają (Newman, 1972).

Powyższe teorie stanowiły istotną podstawę do prowadzenia badań w zakresie przestrzennego rozmieszczenia przestępstw (podobnie jak te wywodzące się z socjologicznej szkoły chicagowskiej np. teoria dezorganizacji społecznej). Co istotne jednak, a co już podkreślono, nie powstały one bezpośrednio na gruncie badań geograficznych, jednak przez naukowców stosowane były w ramach tego rodzaju analiz. Geograficzne analizy zjawiska obejmowały swoim zakresem opis, próby wyjaśnienia zaobserwowanych prawidłowości, ale również próby stosowania powstałych teorii i ich uszczegóławiana na podstawie otrzymanych wyników. W tym kontekście należałoby rozgraniczyć nieco dorobek analiz 
geograficznych, jakie powstały w zakresie prezentowanej problematyki, na polskie i światowe, co wynika przede wszystkim z dość istotnych różnic w odniesieniu do stosowanych metod i poruszanej tematyki. O ile światowe badania nad przestępczością charakteryzują się niezwykle szeroką tematyką, a także dość znacznymi osiągnięciami w tym zakresie, o tyle w Polsce analizy zjawiska wydają się skupiać wokół określonych zagadnień, a ponadto obejmują konkretnie zdefiniowane przestrzenie, często nie poszerzając obszaru badań. Wynikać to może z różnych przyczyn, wśród których kilka wydaje się być rzeczywiście bardzo istotnymi. Jedną z ważniejszych jest z całą pewnością dostępność danych statystycznych oraz sposób ich udostępniania na różnych poziomach szczegółowości, co niekoniecznie jest tak samo problematyczne w badaniach prowadzonych na świecie. Ponadto S. Mordwa (Mordwa, 2016), wskazuje także na inne istotne kwestie, do których zaliczyć należy przede wszystkim: stosunkowo późne rozpoczęcie badań nad przestępczością w Polsce wynikające z braku tradycji akademickich, co do podejmowania tego rodzaju problematyki; brak współpracy w zakresie prowadzonych badań pomiędzy różnymi dyscyplinami oraz niskie zainteresowanie lub jego brak w zakresie współpracy ze strony odpowiednich organów lub instytucji, zajmujących się kwestiami ścigania przestępczości, jej ograniczenia etc.

Wśród opracowań światowych nie sposób pominąć pierwszych prac, które wykorzystywały przestrzeń jako istotny element, który może mieć wpływ na rozmieszczenie większej liczby przestępstw w określonych obszarach. Przy czym należy także podkreślić, że rozważania te ukształtowały się znacznie wcześniej niż polskie analizy w tym zakresie i zazwyczaj wskazuje się kilka etapów w kształtowaniu przestrzennych analiz nad zjawiskiem przestępczości, wyróżniając: szkołę kartograficzną, szkołę chicagowską, etap dominacji podejścia ilościowego, etap jednoczesnego rozwoju przestrzennych analiz kryminologicznych oraz początki zainteresowań w zakresie geograficznych rozważań nad przestępczością oraz współczesne badania nad zjawiskiem (tab. 1).

Wśród opracowań kartograficznych należy wymienić przede wszystkim pracę A.M. Guerrego oraz A. Queteleta, którzy jako pierwsi zastosowali mapy przedstawiające wskaźniki dotyczące wielkości zjawiska odnoszące się od 86 francuskich departamentów i na tej podstawie stwierdzono, że pewne wzorce przestrzenne przestępczości występują i dodatkowo są względnie stałe w czasie (Friendly, 2008). W kolejnej z publikacji Essai sur la Statistique Morlane de la France A.M. Guerry coraz szerzej zastosował metodę kartograficzną w zakresie prezentacji danych statystycznych dotyczących przestępstw. Przy czym jako jedno z pierwszych, opracowanie obejmowało nie tylko prezentację danych, ale również porównania z innymi czynnikami (Friendly, 2007). Podobnie badania A. Queteleta wskazywały na pewne zależności między wielkością przestępczości, a wybranymi cechami

Tabela 1. Etapy rozwoju analiz przestrzennych przestępczości Stages to the development of spatial analysis relating to crime

\begin{tabular}{|c|c|l|l|l|}
\hline \multicolumn{1}{|c|}{$\begin{array}{c}\text { Etap I } \\
\text { (XIX w.) }\end{array}$} & \multicolumn{1}{c|}{$\begin{array}{c}\text { Etap II } \\
(1920-1940)\end{array}$} & $\begin{array}{c}\text { Etap III } \\
(1950-1970)\end{array}$ & $\begin{array}{c}\text { Etap IV } \\
\text { (od 1970) }\end{array}$ & \multicolumn{1}{c|}{$\begin{array}{c}\text { Etap V } \\
\text { (XXI w.) }\end{array}$} \\
\hline $\begin{array}{l}\text { szkoła kartograficzna; } \\
\text { Guerry i Quetelet }\end{array}$ & $\begin{array}{l}\text { szkoła chicagowska } \\
\text { - ekologiczna; } \\
\text { Shaw i McKay }\end{array}$ & $\begin{array}{l}\text { analizy ilościowe; } \\
\text { Morris, Lander }\end{array}$ & $\begin{array}{l}\text { geografia przestępczości; } \\
\text { Harries, Herbert, } \\
\text { kryminologia środowiskowa; } \\
\text { Brantingham i Brantingham }\end{array}$ & $\begin{array}{l}\text { Crime Mapping; } \\
\text { Chainey i Ratcliffe }\end{array}$ \\
\hline
\end{tabular}

Źródło/Source: Mordwa, 2013. 
- m.in. wiekiem, płcią (Quetelet, 1842). Podobne analizy prowadzono dla obszaru Wielkiej Brytanii - publikacje: W. Rawson, An Inquiry into the Statistics of Crime in England and Wales dotycząca Anglii i Walii; H. Mayhew'a - analiza obszarów obarczonych ubóstwem na terenie różnych regionów i miast w Anglii (Mordwa, 2013); T. Plint'a (1974) - przestępczość w powiatach w Anglii oraz jej zróżnicowanie.

Ważnych podsumowań w zakresie rozważań nad zjawiskiem przestępczości w różnych skalach, jak również wskazując na istotność kierunku szkoły kartograficznej dokonali P.J. i P.L. Brantingham. Stwierdzono, że przestrzenne rozmieszczenie przestępstw jest znacznie zróżnicowane i występuje zazwyczaj wraz z innymi zjawiskami, m.in. gęstością ludności, poziomem edukacji lub ubóstwa. Ponadto potwierdzono jeszcze raz względną trwałość w czasie pewnych przestrzennych wzorców zjawiska, co następnie zostało zauważone i docenione w ramach profilaktyki kryminalnej. Założenia te znalazły swoje późniejsze odzwierciedlenie we wspomnianych już koncepcjach (Brantingham i Brantingham, 1991). Inne podejście, tzw. „ekologiczne” zostało wprowadzone przez C. Shaw’a i H. McKay’a. W ramach analiz nad zjawiskami patologii społecznej oraz rozmieszczeniem i/lub koncentracją tego rodzaju zdarzeń na terenie miast zdefiniowano pojęcie obszarów przestępczych, czyli takich, które charakteryzują się określonym zestawem cech, m.in. destabilizacją składu mieszkańców, stosunkowo wysoką gęstością zaludnienia, relatywnie złym stanem zabudowy czy też infrastruktury, co jednocześnie wpływa na ich izolację, a przez to także częstsze występowanie tam zachowań niepożądanych społecznie (Shaw i McKay, 1942). Badania te prowadzono jednak przy uwzględnieniu także cech osobowościowych sprawców przestępstw, przez co spowodowało to dość dużą indywidualizację otrzymanych wniosków oraz krytykę co do możliwości ich stosowania w odniesieniu do powszechnych sytuacji (Piotrowski, 1966). Jednakże na podstawie przeprowadzonych badan możliwe stało się zdefiniowanie teorii dezorganizacji społecznej, na podstawie której wskazano, ze zachowania niepożądane lub też inaczej niewłaściwe są skutkiem nie tylko cech indywidualnych, ale szerszego spektrum czynników o charakterze społeczno-kulturowym (Chainey i Ratcliffe, 2005).

Rozważania nad zjawiskiem przestępczości prowadzono w różnych skalach uwzględniając różnorodne czynniki mające wpływ na zwiększenie wielkości zjawiska. Niewątpliwie kierunek chicagowski uznaje się za jeden z najbardziej istotnych w kontekście prowadzenia badań w skali miejskiej oraz lokalnej (Sypion-Dutkowska, 2014). Jednak dopiero geografia, a właściwie geografia przestępczości, która wykształciła się na styku kryminologii i geografii nieco rozszerzyła zakres badań. Poza identyfikacją i opisem przestrzennego zróżnicowania zjawiska, coraz więcej uwagi poświęcano jego interpretacji, poszukiwaniom przyczyn oraz wyjaśnianiem różnych zależności przestrzennych na poziomie krajowym, regionalnym, miejskim oraz lokalnym (Evans i Herbert, 1989; Herbert, 1982). W tym kontekście warto wspomnieć także o opracowaniu D.K. Harriesa - The Geography of Crime and Justice, które w znaczący sposób zdynamizowało rozwój badań geograficznych nad przestępczością, podkreślając istotę opracowań kartograficznych w tym względzie. Ponadto w ramach wspomnianej publikacji pojawiły się różnorodne metody analiz przestrzennych, które dodatkowo potwierdziły istotność badań geograficznych (Harries, 1974, 1980). Późniejsze opracowania D. Herberta (1982) czy P. i P. Brantingham (1991) również silnie opierały się na stosowaniu różnorodnych metod w zakresie analizy zjawiska, wskazując jednak na konieczność prowadzenia badań nie tylko na poziomie miasta (skala mezo), ale również w ujęciu krajowym i regionalnym (skala makro) czy nieco bardziej lokalnym (skala mi- 
kro). W tym kontekście ważne staje się przystosowanie odpowiednich metod dla każdego ze wskazanych poziomów odniesienia. Podsumowanie badań prowadzonych w zakresie geografii przestępczości zawarto w opracowaniu D. Evansa i D. Herberta The geography of crime (1989). Objęło ono uporządkowanie terminologii oraz metodologii stosowanej w ramach nowej dziedziny.

Szczególnie istotne było wprowadzenie do analiz geograficznych narzędzi dostępnych w ramach GIS, co zapoczątkowało nowy etap w zakresie przestrzennych analiz nad zjawiskiem przestępczości oraz upublicznienie danych o wielkości zjawiska, co pozwoliło na znaczne poszerzenie badań (Mordwa, 2013; Brownlow, 2005; Madge, 1997; Modly 2009). Pojawiły się serwisy internetowe prezentujące wielkość zjawiska: www.crimereports.com, www.spotcrime.com. Kolejne opracowania, wśród których należy wskazać prace G. Rengerta (1989) i H. Simone'a (Rengert i Simon, 1981), J. LeBau'a (1987) oraz K. Harriesa (1974, 1980) wykorzystywały w badaniach kryminologicznych oprogramowanie oraz narzędzia, a to z kolei przyczyniło się do rozwoju przestrzennego podejścia do rozważań nad przestępczością. Ponadto pojawiło się wiele różnych technik, które obejmowały także wpływ środowiska na wielkość zjawiska, motywacje sprawcy etc. Wprowadzono do badań nad zjawiskiem takie techniki jak Crime Mapping, Pro Map, a także profilowanie geograficzne, które jednocześnie miały udoskonalić techniki służb policyjnych w poszukiwaniu przestępców (Mordwa, 2013).

Obszerność badań światowych nad zagadnieniem przestępczości uniemożliwia wskazanie wszystkich istotnych w tym zakresie publikacji czy opracowań. Natomiast należy wskazać, że koncentrują się one wokół określonych zagadnień, do których zaliczyć można:

a. analizy nad mechanizmem działania sprawców przestępstw, a zatem rozważania nad motywacją postępowania przestępców, funkcjonowania w określonych przestrzeniach, postrzegania otoczenia i potencjalnych ofiar;

b. rozważania w zakresie przestrzennego rozkładu zjawiska przy uwzględnieniu różnorodnych czynników, w tym również motywacji sprawców - obejmują charakterystyki miejsc przestępstw oraz identyfikację przyczyn wynikających z samej przestrzeni skłaniających do popełnienia przestępstwa;

c. opracowania obejmujące testowanie różnych koncepcji kryminologicznych lub kryminologiczno-geograficznych mające na celu potwierdzenie określonych założeń w różnych uwarunkowaniach;

d. opracowania dotyczące metod badania zjawiska obejmujące swoim zakresem rozważania nad stosowanymi narzędziami oraz ich doskonaleniem (Lisowska-Kierepka, 2019).

Światowe badania nad przestępczością charakteryzuje dość szerokie i jednoczesne uporządkowanie w zakresie prowadzonych analiz. Wynika to wprost z dostępności danych statystycznych na dużym poziomie szczegółowości - zasadniczo w każdej skali przestrzennej, od większych obszarów aż do punktów adresowych. Zupełnie inaczej należy podsumować dorobek polskich badań nad przestępczością. Zazwyczaj są to pojedyncze prace tematycznie obejmujące rozmaite zagadnienia. Trudno także wyróżnić opracowania, które formułowałyby nowe koncepcje, co wynika zasadniczo z postaci udostępnianych danych statystycznych i stosunkowo słabym rozwoju badań w tym zakresie, na co wskazują niektórzy badacze (Mordwa, 2016). W związku z tym zazwyczaj wskazuje się na kilka grup wokół, których skupiają się opracowania powstałe w tym zakresie (m.in. Sypion-Dutkowska, 2014): 
1. badania dotyczace rozmieszczenia i zmienności czasowej przestępstw, obejmujące rozważania dotyczące zróżnicowania w zakresie występowania przestępczości głównie w przestrzeni dużych miast - w szczególności Łodzi (Mordwa, 2003; Marcińczak i Siejkowska, 2009) i Szczecina (Sypion-Dutkowska, 2010a) (gdzie powstało i powstaje stosunkowo dużo opracowań), a ponadto Gdyni, Wrocławia (Głaz i llnicki, 2004), Poznania (Bogacka, 2009), Krakowa (Krajewski 2008; Mydel i Kozimor, 1989) czy Warszawy (Bartnicki, 1986,1987, 1988). Co należy podkreślić większość z nich opiera się na danych przyporządkowanych do poziomu okręgów policyjnych, co jednocześnie pozwala na bardzo uogólnione rozważania nad omawianą problematyką i uniemożliwia prowadzenie nieco bardziej pogłębionych analiz w tym zakresie. Współcześnie powstałe opracowania wykorzystują dane coraz bardziej szczegółowe, które umożliwiają wyznaczanie tzw. hot spotów, a przez to także inne rozważania dotyczące koncentracji w poszczególnych obszarach miasta, a przez to nieco bardziej poszerzoną interpretację;

2. analizy percepcji zjawiska, jej postrzegania i kreowania przez różnego rodzaju media, wpływu tej kreacji na postrzeganie wielkości zjawiska przez mieszkańców i poczucia bezpieczeństwa. Opracowania w tym zakresie zostały wykonane dla kilku jednostek i stanowią jedne z dominujących w ramach polskiej geografii przestępczości, m.in. dla: Warszawy (Bartnicki, 1991), Krakowa (Guzik, 2000a, 2000b), a ostatnio także dla Łodzi (Piotrowski, 1966; Marcińczak i Siejkowska, 2009; Mordwa, 2010, 2013), Poznania (Dolata i Kotus, 2004, 2006; Bogacka, 2009, 2017; Bogacka i Siniecka, 2016) i Słubic (Bogacka, 2012). Analizy te powstały w większości na podstawie wywiadów wśród mieszkańców, a ich wyniki są porównywane do statystyk policyjnych. Wyniki badań sprowadzają się zazwyczaj do wskazania w przestrzeni miasta dzielnic dobrych i złych - w odczuciu mieszkańców, a także porównanie z przestępczością rejestrowaną oraz badaniami wiktymizacyjnymi. Istotne miejsce wśród tych rozważań stanowią również te związane $z$ analizą poczucia bezpieczeństwa w zależności od typu zabudowy, wieku lub płci;

3. analizy występowania zjawiska w określonych przestrzeniach, przyczyny znacznej koncentracji przestępstw w niektórych obszarach w zależności od ich zagospodarowania, działalności tam występujq̨cych, a także ze względu na cechy demograficzne i inne społeczeństw je zamieszkujqcych - są to jednak jeszcze stosunkowo rzadkie opracowania i obejmują swoim zakresem przede wszystkim rozważania nad natężeniem przestępczości i jego uwarunkowaniami zależnie od m.in. warunków zagospodarowania, w tym jakości zabudowy, warunków mieszkaniowych, wykształcenia ludności, problemów tam występujących (alkoholizm, narkomania i inne). Prace w tym zakresie powstały przede wszystkim dla Torunia (Pióro, 1962; Maik, 1995), Piły, Świecia, Inowrocławia, ale również Warszawy (Kossowska, 1993), Poznania (Dolata i Kotus 2004, 2006) i Szczecina (Sypion-Dutkowska, 2010, 2012, 2014). Bardzo nieliczne, aczkolwiek wykonywane w ramach tych zagadnień opracowania dotyczą także miejsc występowania przestępstw w odniesieniu do miejsc zamieszkania potencjalnych sprawców (podejrzanych) (m.in. opracowania dotyczące Łodzi);

4. opracowania zwiqzane z analizami miejsc zamieszkania sprawców przestępstw oraz przestrzennych czynników warunkujqcych ich zachowania, które ze względu na dostępność tego rodzaju danych (obostrzenia prawne) stanowią niewielki odsetek opracowań nad problematyką przestępczości. Powstałe opracowania dotyczą 
zatem głównie podejrzanych o popełnienie przestępstwa i porównań otrzymywanych wniosków z założeniami teoretycznymi i wnioskami pochodzącymi z badań przeprowadzonych w innych krajach (Jaroszewska-Brudnicka, 2001);

5. opracowania metodologiczne i teoretyczne nad problematykq przestępczości są to jeszcze stosunkowo rzadkie opracowania i stosunkowo mało pogłębiane, co wynika z dostępności i agregacji danych statystycznych udostępnianych przez policję. Wszelkie podejmowane w tym zakresie próby stanowią raczej omówienie dotychczasowego dorobku badań w zakresie analizowanej problematyki. Pojawiające się prace metodologiczne czy teoretyczne obejmujące przestępczość jako jedno z wielu zagadnień dotyczą badania problemów bezpieczeństwa w mieście (Goldschneider, 2010; Bogacka, 2012; Mordwa, 2012, 2015; Sypion-Dutkowska, 2014).

Biorąc pod uwagę dość duże zróżnicowanie tematyczne i metodologiczne polskich badań nad przestępczością, istotniejsze w tym zakresie stają się otrzymane wnioski, które przedstawiono w poniższej tabeli (tab. 2).

Tabela 2. Wnioski wynikające z polskich badań nad zjawiskiem przestępczości Conclusions from Polish research into criminality

\begin{tabular}{|c|c|}
\hline 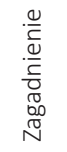 & Główne wnioski ogólne \\
\hline 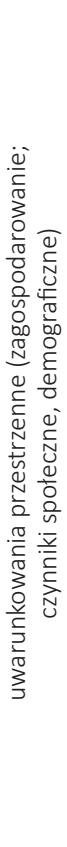 & 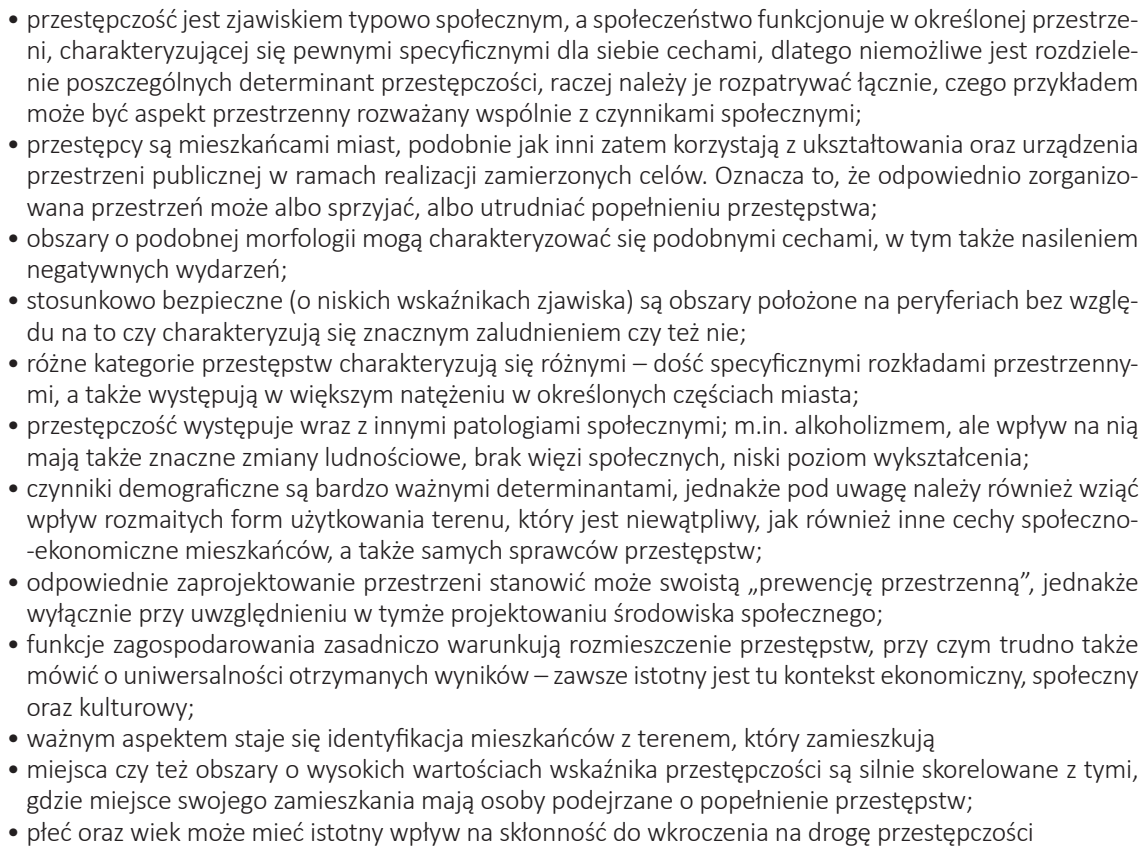 \\
\hline
\end{tabular}




\begin{tabular}{|c|c|}
\hline 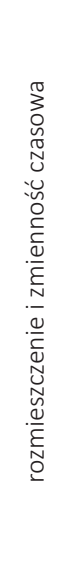 & $\begin{array}{l}\text { - przestępczość jest domeną wielkich miast, urbanizacja sprzyja wzrostowi przestępczości (głównie kra- } \\
\text { dzieżom, przestępstwom z użyciem przemocy; wielkość zjawiska rośnie proporcjonalnie z wielkością } \\
\text { miasta; w wielkich miastach największy udział w ogólnej liczbie stanowią przestępstwa przeciwko } \\
\text { mieniu prywatnemu, a w małych te skierowane przeciwko człowiekowi (uszkodzenia ciała oraz bójki); } \\
\text { - zróżnicowanie przestrzenne przestępczości jest stosunkowo trwałe w czasie; } \\
\text { - w przestrzeni miasta zawsze można wskazać obszary niebezpieczne i te niezagrożone lub w znacznie } \\
\text { mniejszym stopniu zagrożone przestępczością; obszarami o największym nasileniu zjawiska są zwykle } \\
\text { centra miast, natężenie spada wraz z oddalaniem się od centrum; wyższe wskaźniki przestępczości } \\
\text { dotyczą obszarów o funkcjach administracyjnych, handlowych, komunikacyjnych, rozrywkowych, } \\
\text { a także tych niegdyś przemysłowych lub przemysłowo-mieszkaniowych, a obecnie zdegradowanych; } \\
\text { - zjawisko wykazuje sezonowość występowania w różnych skalach przestrzennych - w tzw. cieplejszej } \\
\text { części roku (kwiecień-sierpień) zdarzeń jest nieco więcej niż w zimnej (wrzesień-marzec); warunki po- } \\
\text { godowe mają również istotne znaczenie; najbezpieczniej jest w lipcu, stosunkowo mało przestępstw } \\
\text { występuje w listopadzie i grudniu; w dużych miastach (w takich prowadzone były analizy) w dni robo- } \\
\text { cze (od poniedziałku do czwartku) wielkość zjawiska utrzymuje się zasadniczo na tym samym pozio- } \\
\text { mie dla każdego z rodzajów przestępstw; pod koniec tygodnia wielkość zjawiska wzrasta. } \\
\text { - występują różnice w natężeniu zjawiska między wschodnią i zachodnią częścią kraju, a znaczne nasi- } \\
\text { lenie przestępczości wykazano na terenie dużych miast }\end{array}$ \\
\hline 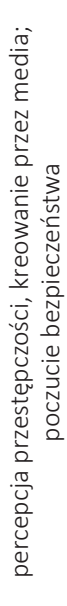 & $\begin{array}{l}\text { - obszary o znacznym nasileniu przestępstw zwykle postrzegane są przez mieszkańców miasta również } \\
\text { jako niebezpieczne - nie jest to jednak tożsame z wielkością zjawiska postrzeganą przez mieszkańców } \\
\text { zasiedlających takie obszary - co wynika z wyparcia zagrożenia poza obszar zamieszkania oraz statysty- } \\
\text { kami policyjnymi; } \\
\text { - brak poczucia bezpieczeństwa mieszkańców miast lub też lęk przed przestępczością ma złożoną genezę, } \\
\text { która jest konsekwencją nie tylko samych rodzajów przestępstw, ale również wiąże się nieodzownie ze spe- } \\
\text { cyficznymi cechami samej przestrzeni, jej ładu i zagospodarowania, jak również warunków funkcjonowania } \\
\text { w ośrodkach miejskich; strach wynika także z warunków życia, w których funkcjonują mieszkańcy; } \\
\text { - większość osób określa pewne dzielnice miast jako niebezpieczne, nie wskazując jednocześnie uwarun- } \\
\text { kowań o charakterze społecznym, jak np. alkoholizm i innych negatywnych zjawisk, wymieniając wśród } \\
\text { elementów kształtujących negatywny odbiór takich obszarów: stan infrastruktury mieszkaniowej, zanie- } \\
\text { dbanie, brak w ciągłości zabudowy, złe warunki bytowania ludności, ogólny nieporządek oraz znaczne } \\
\text { zagęszczenie mieszkańców - rosnąca anonimowość - stereotypizacja przestrzenna; } \\
\text { - bardzo często wiedza na temat zjawiska przestępczości, jak również wyobrażenie o nim wynika z prze- } \\
\text { kazu medialnego, to z kolei utrwala w świadomości mieszkańców negatywne postrzeganie niektórych } \\
\text { obszarów w obrębie określonej jednostki terytorialnej } \\
\text { - poczucie bezpieczeństwa mieszkańców jest zależne m.in. od wielkości ośrodka poddanego analizie - } \\
\text { w mniejszych miastach opinie te są zazwyczaj bardziej jednorodne, co jest zasadniczo odmienne w przy- } \\
\text { padku dużych lub wielkich miast, gdzie postrzeganie to różnicuje się w poszczególnych dzielnicach }\end{array}$ \\
\hline 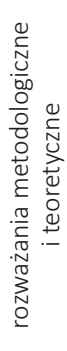 & $\begin{array}{l}\text { - nie można mówić o prostym przeniesieniu sposobów i technik amerykańskich przedstawicieli nurtu eko- } \\
\text { logicznego do polskich realiów, co wynika ze specyfiki poszczególnych miejsc/miast/obszarów; } \\
\text { - w ramach przestrzennych analiz nad zjawiskiem przestępczości, w polskich badaniach, coraz częściej } \\
\text { wykorzystywane są różne metody geostatystyczne - uzależnione jest to przede wszystkim od postaci } \\
\text { danych statystycznych jakimi dysponuje badacz - m.in. metoda k-średnich umożliwiająca prowadzenie } \\
\text { analiz nad zróżnicowaniem przestrzennym przestępczości w kontekście wskazania określonych typów } \\
\text { obszarów wykorzystując różne zmienne, autokorelacja przestrzenna stosowana wanalizach dotyczących } \\
\text { natężenia różnych kategorii przestępstw; metoda regresji przestrzennej używana do wskazania przy- } \\
\text { czyn zmienności przestrzennej danego przestępstwa przy uwzględnieniu m.in. cech demograficznych } \\
\text { - } \text { społeczeństwa }\end{array}$ \\
\hline
\end{tabular}

Źródło/Source: Lisowska-Kierepka, 2019. 


\section{Podsumowanie}

Przestępczość jest zjawiskiem złożonym, a przez to także skomplikowanym obejmującym kilka różnych elementów - sprawcę, ofiarę, czyn oraz czas, które mogą podlegać rozważaniom w różnych kontekstach. W centrum zainteresowania znalazły się rozważania nad takimi zagadnieniami jak: dlaczego człowiek dokonuje czynów niezgodnych z prawem? jakie są tego przyczyny - czy tkwią w jednostce, czy też związane są z czynnikami zewnętrznymi? gdzie i kiedy występuje przestępczość na wyższym niż przeciętnie poziomie? kim są ofiary przestępstw? Można wymienić tu jeszcze wiele innych interesujących zagadnień, ale wyżej wskazane, z uwagi na potrzeby zapewnienia bezpieczeństwa i przeciwdziałania problemowi, stanowią te najczęściej rozpatrywane. Stąd też zagadnienie to stało się przedmiotem analiz wielu różnych dyscyplin naukowych, w różnym zakresie. Przegląd badań nad zjawiskiem przestępczości zaprezentowano w trzech najważniejszych ujęciach, uwzględniając przestrzeń jako istotny czynnik, który poza sprawcą i ofiarą przestępstwa powinien być rozpatrywany w ramach analiz nad zjawiskiem.

Na podstawie powyższych rozważań wskazano następujące wnioski:

- pierwsze prowadzone badania skoncentrowane były wokół różnych specjalistów - przedstawicieli różnych dziedzin, które jednak skupiały się wokół jednej nauki kryminologii, przez co uznana została za wiodącą w tym zakresie. Tu przyporządkowano większość powstałych teorii; dopiero później przestępczość stała się także przedmiotem badań innych nauk, spośród których dość szczegółowo podlegała analizom w ramach socjologii, a później geografii. Dlatego większość prowadzonych badań można zaliczyć do trzech głównych podejść - kryminologicznego, socjologicznego i geograficznego, które przenikają się wzajemnie;

- przestrzenny aspekt rozważań nad przestępczością towarzyszący różnym badaniom stał się domeną badań geograficznych (ze względu na specyfikę tej dyscypliny naukowej) i to do nich przypisywane są zazwyczaj rozważania w tym zakresie, co związane jest przede wszystkim z czynnikiem przestrzennym, chociaż należy wskazać także na osiągnięcia w zakresie socjologii czy kryminologii, które nierzadko odwołują się do uwarunkowań przestrzennych;

- podejście geograficzne w badaniach nad zjawiskiem jest dość specyficzne - brak sformułowanych koncepcji lub teorii, a rozważania prowadzone w tym zakresie mieszczą się w zakresie geografii przestępczości - subdyscypliny łączącej zagadnienia na pograniczu kryminologii, socjologii i geografii;

- badania nad przestępczością w ujęciu geograficznym w literaturze światowej i polskiej są znacznie zróżnicowane, co uwarunkowanie jest przede wszystkim dostępnością i postacią danych statystycznych, jak również ich dokładnością. W Polsce trudno uzyskać bardzo szczegółowe dane przestrzenne dotyczące lokalizacji przestępstw, jak również ich sprawców, co z kolei nie stanowi większego problemu w rozważaniach zagranicznych, stąd zróżnicowanie wynikające z zakresu poruszanych zagadnień, liczby badań i publikacji.

- nie należy rozdzielać analiz nad zjawiskami trudnymi, złożonymi, które swoim zakresem dotyczą różnych aspektów funkcjonowania społeczeństwa - takim bez wątpienia jest przestępczość - pomiędzy różne dyscypliny naukowe. Stąd też podkreśla się, że konieczna jest w tym kontekście współpraca wielu różnych dyscyplin naukowych (por. Radzinowicz, 1961); 
- istotną rolę w zakresie interdyscyplinarnych rozważań nad przestępczością odgrywa geografia, jako nauka integrująca wiele różnych podejść teoretycznych i metodologicznych.

Przestępczość jest zjawiskiem skomplikowanym, z pewnością można wskazać, że społecznym - zarówno jeśli definiowane będzie przez pryzmat społeczeństwa jako głównego podmiotu, którego dotyczy, jak i w kontekście rozważań teoretycznych, a więc kiedy rzeczywiście się takim zjawiskiem staje. Czynniki społeczne, czy społeczno-ekonomiczne warunkujące różnorodne zjawiska stanowią także przedmiot zainteresowania geografii, a właściwie geografii społecznej, która koncentruje się wokół zagadnień związanych z człowiekiem i jego działalnością.

Jak już wskazano, przestępczość jest zjawiskiem, które uwzględnia trzy elementy działanie człowieka odpowiednio zmotywowanego, cel oraz czas i miejsce tego działania. O ile pierwsze dwa elementy podlegały szerokim analizom od samego początku, o tyle miejsce (a także czas) popełnienia przestępstwa pojawiło się nieco później w rozważaniach nad tą problematyką. Natomiast to domeną geografii jest uwzględnienie w różnego rodzaju analizach czynnika przestrzennego - przestrzeń odgrywa tu znaczącą rolę, nie stanowi jedynie tła dla występujących zjawisk, ale wchodzi z nimi w różnego rodzaju interakcje. Przestrzenne analizy nad zjawiskiem zaznaczyły się w obrębie różnych dyscyplin naukowych, jednak do wiodących w zakresie teoretycznym należały kryminologia i socjologia. Z kolei w ramach geografii, która nie wykształciła, żadnych podstaw teoretycznych wyjaśniających występowanie zjawiska, specyfika badań związana była i jest przede wszystkim z praktycznym wykorzystaniem istniejących założeń teoretycznych i poszukiwaniem związków między negatywnymi zjawiskami a przestrzenią, w której występują.

Czy przestępczość jest zjawiskiem geograficznym? Zakłada się, że można je jako takie określić - w świetle współcześnie prowadzonych analiz obejmuje swoim zakresem człowieka działającego w określonym środowisku, które z różnych względów może sprzyjać podjęciu decyzji, a dalej popełnieniu przestępstwa; bierze pod uwagę różnego rodzaju uwarunkowania społeczne czy gospodarcze, a także ich kombinację, które mogą stanowić istotne determinanty pojawienia się przestępczości (zagadnienia te, jak wskazano wcześniej, leżą w zakresie zainteresowań geografii społecznej). Mimo że geografia jako nauka nie tworzy i nie definiuje żadnych teorii w zakresie występowania zjawiska, to z pewnością dostarcza wielu przydatnych narzędzi i metod, które pozwalają na szersze analizy przestępczości w ujęciu przestrzennym. Współcześnie podkreśla się, że analiza miejsca, w którym popełniono przestępstwo jest niezwykle ważne w kontekście zrozumienia przyczyn, a tym samym ograniczenia samego zjawiska, co jednocześnie dodatkowo wskazuje na istotność badań geograficznych (Chainey i Ratcliffe, 2005).

Przestępczość jest z całą pewnością zjawiskiem niezwykle złożonym i wielowątkowym, które współcześnie rozpatrywane jest przez różne dyscypliny naukowe. Interdyscyplinarne ujęcie umożliwia znacznie szersze rozważania i bardziej kompleksowe podejście, co zwłaszcza w przypadku zjawisk niebezpiecznych jest niezwykle istotne. 


\section{Piśmiennictwo}

Bandura A., 1979, The Social Learning Perspective, [w:] H. Toch (red.), Psychology of Crime and Criminal Justice, Waveland Press, New York, s. 198-236.

Bartnicki S. 1987, Geografia przestępczości miejskiej, [w:] A. Rajkiewicz, Z. Tokarski (red.), Zagrożenia społeczne i warunki oraz środki ich przezwyciężania. Polska 2000, 2/1986, II, s. 37-48

Bartnicki S., 1986, The geography of crime. A case study of Warsaw, Miscellanea Geographica, s. $237-242$.

Bartnicki S., 1988, Spatial images of crime in Warsaw, Miscellanea Geographica, s. 267-275.

Bartnicki S., 1991, Percepcja zagrożenia przestępczościq - wstępna prezentacja wyników badań przeprowadzonych w 12 warszawskich osiedlach mieszkaniowych, Conference Papers IGiPZ PAN, 14, Warszawa, s. 117-124.

Błachut J., 2007, Problemy zwiqzane z pomiarem przestępczości, Wolters Kluwer Polska, Warszawa. Błachut J., Gaberle A., Krajewski K., 2007, Kryminologia, Wyd. Arche, Gdańsk.

Bogacka E., 2009, Przestępczość w Poznaniu, Biuletyn Instytutu Geografii Społeczno-Ekonomicznej i Gospodarki Przestrzennej, Seria Rozwój Regionalny i Polityka Regionalna, 6, Poznań, s. 87-100.

Bogacka E., 2012, Zastosowanie teorii społecznej dezorganizacji do badania zróżnicowania przestrzennego przestępczości, Wiadomości Statystyczne, 1, s. 43-51.

Bogacka E., 2017, Problematyka badawcza z zakresu poczucia bezpieczeństwa człowieka w przestrzeni miasta, Acta Universitas Lodziensis, Folia Geographica Socio-Oeconomica, 27, s. 141-151.

Bogacka E., Siniecka A., 2016, Poczucie bezpieczeństwa mieszkańców miasta. Przykład Poznania, Rozwój Regionalny i Polityka Regionalna 33, s. 57-71.

Brantingham P.J., Brantingham P.L., 1991, Notes on the geometry of crime, [w:] P.J. Brantingham, P.L. Brantingham (red.), Environmental Criminology, Waveland Press, Prospect Heights, s. 27-54. Brownlow A., 2005, A geography of men's fear, Geoforum, 36, s. 581-592.

Chainey S., Ratcliffe J., 2005, GIS and Crime Mapping, John Wiley \& Sons, Hoboken.

Cloward R., Ohlin L.E., 1960, Delinquency and Opportunity, The Free Press Glencoe, New York.

Cohen A., 1955, Delinquent Boys. The Culture of the Gang, The Free Press Glencoe, New York.

Czarnecki B., 2011, Przestrzenne aspekty przestępczości. Metoda identyfikacji czynników zagrożeń w przestrzeni miejskich, Rozprawy Naukowe nr 216, Oficyna Wydawnicza Politechniki Białostockiej, Białystok.

Czyż T., 1996, Issues in Social Geography, [w:] Z. Chojnicki (red.), Contemporary Problems of Polish Geography, Bogucki Wydawnictwo Naukowe, Poznań, s. 57-67.

Doran B.J., Lees B.G., 2005, Investigating the Spatiotemporal Links Between Disorder, Crime, and the Fear of Crime. The Professional Geographer, 57 (1), s. 1-12.

Dolata M., Kotus J., 2004, Społeczne naznaczanie obszarów miasta, [w:] I. Jażdżewska (red.), Zróżnicowanie warunków życia ludności w mieście, Łódź, s. 245-256.

Dolata M., Kotus J., 2006, Social Production of Urban Space. A Case Study Of 'Bad' Areas in Poznań, Geographia Polonica, 79, 2, s. 5-22.

Drzazga E., Grzyb M., 2018, Nowe kierunki w kryminologii, Wyd. Naukowe Scholar, Warszawa.

Eck J.E., Weisburd D., 1995, Crime Places in Crime Theory, [w:] J.E. Eck, D. Weisburd (red.), Crime and Place, Crime Prevention Studies, 4, Criminal Justice Press, New York, s. 1-34.

Evans D.J., Herbert D.T. (red.), 1989, The Geography of Crime, Routledge, New York.

Eysenck H.J., 2013, Crime and Personality (Psychology Revivals), Routledge, London-New York. 
Felson M., 2009, Linking Criminal Choice, Routine Activities, Informal Control and Criminal Outcomes, [w:] K. Moss (red.), Crime Reduction, Critical Concepts in Criminology. Volume II Motivation of the Criminal Inclination, Routledge, New York, s. 119-128.

Felson M., Gottfredson M., 1984, Social indicators of adolescent activities near peers and parents, Journal of Marriage and the Family, 46, s. 709-714.

Friendly M., 2007, A.-M. Guerry's Moral Statistics of France: Challenges for Multivariable Spatial Analysis, Statistical Science, 22, 3, s. 368-399.

Friendly M., 2008, The Golden Age of Statistical Graphics, Statistical Science, 23, 4, s. 502-535.

Giddens A., Sutton P.W., 2012, Socjologia wydanie nowe, PWN, Warszawa.

Głaz M., IInicki D., 2004, Przestępstwa i wykroczenia w przestrzeni Wrocławia [w:] J. Słodczyk (red.), Przemiany struktury przestrzennej miast w sferze funkcjonalnej i społecznej, Uniwersytet Opolski, Opole, s. 347-361.

Goldschneider M., 2010, Geografia przestępczości. Uwagi na temat przestrzennych analiz przestępczości przy wykorzystaniu technik cyfrowych, Archiwum Kryminologii, 32, s. 23-43, http://www. inp.pan.pl/wydaw/AK32\%20Goldschneider.pdf (05.05.2018).

Gottfredson M., Hirschi T., 1990, A General Theory of Crime, Stanford University Press, California.

Gregory D., Johnston R., Pratt G., Watts M., Whatmore A., 2009, The Dictionary of Human Geography, Wiley-Blackwell, Chichester.

Guzik R., 2000a, Przestępczość w przestrzeni miejskiej Krakowa w wyobrażeniach jego mieszkańców, [w:] I. Jażdżewska (red.), Miasto postsocjalistyczne - organizacja przestrzeni miejskiej i jej przemiany, ŁTN, Łódź, s. 201-204.

Guzik R., 2000b, Przestrzenny obraz przestępczości w prasie krakowskiej, [w:] B. Domański (red.), Studia nad rozwojem lokalnym i regionalnym, Prace Geograficzne, Instytut Geografii UJ, 106, s. $197-216$.

Hanausek T., 1998, Kryminalistyka. Zarys wykładu, Kantor wyd. Zakamycze, Kraków.

Harries K.D., 1974, The Geography of Crime and Justice, McGraw-Hill, New York.

Harries K.D., 1980, Crime and the Environment, Charles C. Thomas Publisher, Springfield.

Herbert D.T., 1982, The Geography of Urban Crime, Longman, Harlow.

Herbert D.T., 1989, Crime and place: an introduction, [w:] D. Evans, D. Herbert (red.), The Geography of Crime, Routledge Press, London, s. 1-15.

Hołyst B., 2009, Kryminologia, LexisNexis, Warszawa.

Jaroszewska-Brudnicka R., 2001, Zmienność czasowa i przestrzenna zjawiska przestępczości w Toruniu w latach dziewięćdziesiątych, [w:] I. Sagan, M. Czepczyński, Wybrane problemy badawcze geografii społecznej w Polsce, Gdynia, s. 181-187.

Kossowska A., 1993, Środowiskowo-przestrzenne uwarunkowania przestępczości (wybrane zagadnienia współczesnej ekologii przestępczości), Archiwum Kryminologii, 19, s. 7-16.

Krajewski K., 2008, Ogólna charakterystyka nasilenia i dynamiki przestępczości ujawnionej w Krakowie w latach 1990-2005 na tle sytuacji w Amsterdamie, Budapeszcie, Hamburgu i Wiedniu, [w:] K. Krajewski (red.), Poczucie bezpieczeństwa mieszkańców wielkich miast. Kraków na tle innych miast europejskich, WUJ, Kraków, s. 47-83.

LeBeau J.L., 1987, Patterns of Stranger and Serial Rape Offending: Factors Distinguishing Apprehended and At Large Offenders, The Journal of Criminal Law and Criminology, 78, 2, s. 309-32.

Lisowska-Kierepka A., 2019, Obszary zagrożone zjawiskiem przestępczości w przestrzeni wielkich miast (na przykładzie Wrocławia, Krakowa i Poznania), nieopublikowany maszynopis rozprawy doktorskiej, Uniwersytet Wrocławski, Wrocław. 
Lombroso C., 1891, Człowiek - zbrodniarz w stosunku do antropologii jurysprudencji i dyscypliny więziennej, nakładem M. Wołowskiego, Warszawa.

Madge C., 1997, Public Parks and the Geography of Fear, Tijdschrift voor Economische en Sociale Geografie, 88, 3, s. 237-250.

Maik W., 1995, Socio-spatial analysis of crime and delinquency: a case study of Toruń, [w:] B. Gałczyńska, G. Węcławowicz (red.), Urban and regional issues in geographical research in Poland and Italy, Proceeding of the Seventh Polish-Italian Geographical Seminar, Warszawa-Wierzba-Toruń-Łódź, 27.09-2.10.1993, Conference Papers, 24, Warszawa, s. 91-98.

Marcińczak S., Siejkowska A., 2009, Przestępczość w Łodzi. Stan w roku 2002, [w:] S. Liszewski (red.), Atlas miasta Łodzi. Suplement 1, Urząd Miasta Łodzi, Łódź, plansza LII.

Merton R., 1982, Teoria socjologiczna i struktura społeczna, PWN, Warszawa.

Miller W., 1958, Lower Class Culture as a Generating Milieu of Gang Delinquency, The Journal of Social Issues, 24, s. 5-19.

Modly A.R., 2009, Geography of Fear: Understanding Students' Sense of Place, Chrestomathy: Annual Review of Undergraduate Research, College of Charleston, 8, s. 115-146.

Mordwa S., 2003, Przestępstwa w dużych miastach w Polsce (na przykładzie Łodzi), [w:] I. Jażdżewska (red.), Funkcje metropolitalne i ich rola w organizacji przestrzeni, ŁTN, Łódź, s. 209-217.

Mordwa S., 2010, Poczucie bezpieczeństwa mieszkańców wybranych osiedli w Łodzi, [w:] M. Madurowicz (red.), Wartościowanie współczesnej przestrzeni miejskiej, Warszawa s. 307-316.

Mordwa S., 2012, Struktura i typologia przestrzenna przestępczości w Polsce - przykład wykorzystania walidacji liczby skupień w metodzie k-średnich, Acta Universitatis Lodziensis, Folia Geographica Socio-Oeconomica, 12, s. 89-110.

Mordwa S., 2013, Przestępczość i poczucie w przestrzeni miasta. Przykład Łodzi, Uniwersytet Łódzki, Łódź.

Mordwa S., 2015, Techniki GIS - w poszukiwaniu hot spotów przestępczości, Archiwum Kryminologii, 37, s. 279-302.

Mordwa S., 2016, The Geography of Crime in Poland and its interrelationship with other fields of study, Geographia Polonica, 89, 2, s. 187-202.

Mydel R., Kozimor K., 1989, Demograficzne, czasowe i przestrzenne aspekty przestępczości w Krakowie, Folia Geographica, Series Geographica-Oeconomica, 22, s. 63-84.

Newman O., 1972, Defensible Space, Macmillan, New York.

Park R.E., 1952, Human Communities, Free Press, New York.

Pióro Z., 1962, Ekologia społeczna w urbanistyce na przykładzie badań lubelskich i toruńskich, Wyd. "Arkady", Warszawa.

Piotrowski W., 1966, Społeczno-przestrzenna struktura miasta Łodzi. Studium ekologiczne, Zakład Narodowy im. Ossolińskich, Wrocław-Kraków.

Plint T., 1974, Crime in England. Perspectives in Social Inquiry, Arno Press, New York.

Problems of Polish Geography, Bogucki Wydawnictwo Naukowe, Poznań, s. 57-67.

Quetelet M.A., 1842, A Treatise on man and the development of his faculties, W. \& R. Chambers, Edynburg.

Radzinowicz L., 1961, In Search of Criminology, London-Melbourne-Toronto.

Rengert G.F., 1989, Behavioral Geography and Criminal Behavior, [w:] D.J. Evans, D.T. Herbert (red.), The Geography of Crime, Routledge, London, s. 161-175.

Rengert G.F., Simon H., 1981, Crime Spillover, Sage Publications, Beverley Hills.

Shaw C.R., McKay H.D., 1942, Juvenile Delinquency and Urban Areas, University of Chicago Press, Chicago. 
Sutherland E.H., 1947, Principles of criminology, Oxford, Philadelphia.

Sypion-Dutkowska N., 2010, The spatial and temporal car crime analysis in Szczecin (Poland), [w:]

T. Michalski, A. Kuczabski (red.), Selected aspects of transformation in countries of Central and Central-Eastern Europe, Pelplin, s. 153-189.

Sypion-Dutkowska N., 2010a, Bezpieczeństwo publiczne uwarunkowaniem rozwoju lokalnego. Sku-

piska rozbojów i bójek w Szczecinie, [w:] M. Tarkowski, J. Mazurek (red.), Regiony Nadmorskie

18, Wybrane problemy rozwoju lokalnego w Polsce północnej, Gdynia-Pelplin, s. 170-183.

Sypion-Dutkowska N., 2012, Public safety of local development: Hot spots of commercial crimes

in Szczecin, [w:] T. Michalski, A. Radchenko (red.), Global, continental, national and regional conditions of local development, Gdańsk-Kharkiv, s. 146-155.

Sypion-Dutkowska N., 2014, Uwarunkowania przestrzenne przestępczości w wielkim mieście w ujęciu GIS (na przykładzie Szczecina), Studia KPZK PAN, 159, Warszawa.

Sztompka P., 2002, Socjologia. Analiza społeczeństwa, Wyd. Znak, Warszawa.

von Liszt F., 1905, Die Aufgabe und die Methode der Strafrechtswissenschaft, [w:] Strafrechtliche Aufsätze und Vorträge (1899), 1892-1904, Guttentag, Berlin, s. 284-298.

Wortley R., Mazerolle L., 2008, Environmental Criminology and Crime Analysis: Situating in Theory, Analytic Approach and Application [w:] R. Wortley, L. Mazerolle, Environmental Criminology and Crime Analysis, Routledge, London-New York, s. 1-18.

www.crimereports.com (15.02.2019)

www.spotcrime.com (15.02.2019)

\section{Summary}

The functioning of society and specific systems of values have led to a growing interest in difficult and above all dangerous phenomena, including crime. Initial work was based mainly around the perpetrator and his or her motivation, but that approach received justifiable criticism. Equally, the necessity of slightly broader (multi-factor) analyses being carried out was noted more and more often. And with crime being an extremely problematic and therefore important phenomenon, it attracted the interest of many different scientific disciplines, not least history, sociology, law, criminology, the medical sciences and geography. Naturally enough, these disciplines' first forays into the phenomenon were each separate, as were the adopted methodologies, concepts, and so on. The consequence was the recognition of the phenomenon as multidisciplinary, meaning that it was examined individually via a range of different approaches. While such an approach was obviously valid scientifically, it had ultimately to be insufficient - and all the more so given the importance of the phenomenon to the functioning of society. Crime is a phenomenon encompassing many variables, the separate consideration of which only allows for analysis of the given issue as part of a much broader problem.

Ultimately, the response was a change of perception as regards the phenomenon, with it coming to be placed among interdisciplinary studies. Thus, while representatives of various scientific disciplines remained interested in the phenomenon, existing elaborations boil down to three approaches, i.e. the criminological, the sociological and the geographical.

Criminological analyses of the phenomenon are certainly the oldest; and - unsurprisingly - criminology has been seen from the outset as the leading science when it comes 
to criminality and the searching for causes thereof. Research conducted in this area is found to embody three basic approaches in criminological analyses of the causes of crime, i.e. a biological one considering the inheritance of traits and its negative consequences; a sociological one connecting directly with the functioning of society and resulting consequences; and a situational one, regarding spatial factors as some of the most important when it comes to perpetrators' decision-making processes. For its part, sociology treats crime somewhat differently, viewing it as a phenomenon occurring through society's conferment of meaning upon it. This means that the social group in which an individual functions decides what becomes a crime, and when that happens. As with the criminological considerations, various concepts may be identified. However, these also focus in on the person committing the crime, even as consideration is also given to impacts exerted by the society or groups in which an individual functions or hails from. On the other hand, the geographical approach differs greatly, in not having developed concepts justifying the shaping and functioning of the phenomenon. Geographical considerations extend to both the description and the analysis of the phenomenon's spatial occurrence and an attempt to apply existing theories in this regard. However, the output of contemporary research sees global and Polish achievements distinguished mainly in terms of their availability of data. It is undeniable that the scope of research and methodology applied are shaped mainly by international studies, while Polish analyses are directed at the search for new methods of considering the phenomenon.

This study offers a research review relating to crime as an extremely complex phenomenon that should be considered as a whole by representatives of various scientific disciplines. This would allow, not only for scientific considerations, but also for application-based ones. Nevertheless, today's geographical (i.e. spatial) approach would seem to combine various sub-approaches, and thus provide for a comprehensive examination of the problem of crime. 